\title{
PROPOSAL TO IRRADIATE POWER BURST FACILITY FUEL ELEMENTS UNDER STEADY STATE CONDITIONS IN THE ETR M-3 LOOP
}

\author{
by
}

\author{
R. K. Marshazz
}

Fuel Design and Analysis

\section{Apri1 1971}

This report was prepared as an account of work
sponsored by the United States Government. Neither
the United States nor the United States Atomic Energy
Commission, nor any of their employees, nor any of
their contractors, subcontractors, or their employees,
makes any warranty, express or implied, or assumes any
legal liability or responsibility for the accuracy, com-
pleteness or usefulness of any information, apparatus,
product or process disclosed, or represents that its use
would not infringe privately owned rights.

This report is intended primarily for internal use by the sponsoring organization and Battelle-Northwest.

BATTELLE-NORTHWEST

BATTELLE MEMORIAL INSTITUTE

PACIFIC NORTHWEST LABORATORIES

RICHLAND, WASHINGTON 99352 


\section{DISCLAIMER}

This report was prepared as an account of work sponsored by an agency of the United States Government. Neither the United States Government nor any agency Thereof, nor any of their employees, makes any warranty, express or implied, or assumes any legal liability or responsibility for the accuracy, completeness, or usefulness of any information, apparatus, product, or process disclosed, or represents that its use would not infringe privately owned rights. Reference herein to any specific commercial product, process, or service by trade name, trademark, manufacturer, or otherwise does not necessarily constitute or imply its endorsement, recommendation, or favoring by the United States Government or any agency thereof. The views and opinions of authors expressed herein do not necessarily state or reflect those of the United States Government or any agency thereof. 


\section{DISCLAIMER}

Portions of this document may be illegible in electronic image products. Images are produced from the best available original document. 


\section{PAGES i to ii WERE INTENTIONALLY LEFT BLANK}




\section{TABLE OF CONTENTS}

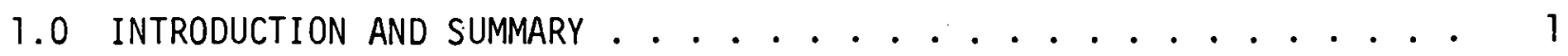

2.0 DESCRIPTION OF TEST COMPONENTS . . . . . . . . . . . 2

2.1 FUEL PELLETS AND RODS ................ 2

2.2 TEST ASSEMBLY . . . . . . . . . . . . . . . . 2

3.0 OPERATING CONDITIONS ...................... 5

4.0 SPECIAL REQUIREMENTS ................ 5

5.0 MECHANICAL ANALYSIS ................. 8

5.1 EXTERNAL COLLAPSE PRESSURE, OPERATING PRESSURE, AND STRESS • • 8

5.2 CLADDING THERMAL STRESSES ............... 10

5.3 COMBINED STRESSES . . . . . . . . . . . . . . 10

5.4 INTERNAL FISSION GAS PRESSURE . . . . . . . . . . . . . 11

6.0 HEAT GENERATION . . . . . . . . . . . . . 13

6.1 FISSION HEAT GENERATION . . . . . . . . . . . . . 13

6.2 GAMMA HEAT GENERATION . . . . . . . . . . . . . . . . . 14

6.3 TEST ASSEMBLY AND FUEL ROD HEAT GENERATION . . . . . . . . 15

7.0 THERMAL-HYDRAULIC ANALYSIS . . . . . . . . . . . . 16

7.1 HYDRAULIC CHARACTERISTICS . . . . . . . . . . . . . . 16

7.2 FUEL ROD SURFACE AND COOLANT TEMPERATURES . . . . . . . . 16

7.3 FUEL THERMAL ANALYSIS . . . . . . . . . . . . . 18

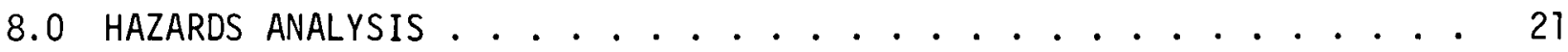

8.1 FUEL ROD-TO-FUEL ROD CONTACT . . . . . . . . . . 21

8.2 FUEL ROD FAILURE ................... 22

9.0 QUALITY ASSURANCE ................... 23

10.0 DRAWINGS OF PBF FUEL ROD AND TEST ASSEMBLY . . . . . . . . . . 24

REFERENCES ................................ 25

APPENDIX A. GAMMA HEAT GENERATION CALCULATIONS .......... IA

APPENDIX B. THERMAL-HYDRAULIC CALCULATIONS ........... IB DISTRIBUTION 


\title{
P.ROPOSAL TO IRRADIATE POWER BURST FACILITY FUEL ELEMENTS UNDER STEADY STATE CONDITIONS IN THE ETR M-3 LOOP
}

\author{
R. K. Marshazz
}

\subsection{INTRODUCTION AND SUMMARY}

Battelle-Northwest was requested to provide assistance to the Idaho Nuclear Corporation to conduct a steady-state irradiation of Power Burst Facility (PBF) fuel elements in the ETR M-3 loop.

The Idaho Nuclear Corporation will provide the PBF fuel rods, dummy rods, spacers, and hardware design. BNW will provide the hardware and has herein provided the design analyses.

The final design of the test assembly consists of a $3 \times 3$ rod array with the rods located on a 0.792 inch pitch. Seven of the positions in the array are occupied by PBF fuel rods and two are occupied by dummy rods. The dummy rods occupy the corner positions nearest to the reactor. The radial flux gradient across the facility causes the power generated in fuel rods located in these positions to exceed the maximum design heat rating.

The maximum design heat rate is $14.5 \mathrm{~kW} / \mathrm{ft}$. The test flow velocity is $11 \mathrm{ft} / \mathrm{sec}$, the loop operating pressure is $600 \mathrm{psi}$, and the coolant inlet temperature is $200^{\circ} \mathrm{F}$.

The PBF production rod fuel contains $30.6 \mathrm{wt} \% \mathrm{UO}_{2}(18.3 \%$ enriched), 62.3 wt\% $\mathrm{ZrO}_{2}$, and 7.1 wt\% $\mathrm{CaO}$. 
BNWL-B-75

\subsection{DESCRIPTION OF TEST COMPONENTS}

\subsection{FUEL PELLETS AND RODS}

The fuel consists of a ternary mixture of $\mathrm{UO}_{2}, \mathrm{ZrO}_{2}$, and $\mathrm{CaO}$ compacted into cylindrical pellets. The active length of the fuel column in each rod is 36 inches. The pellets are contained in $304 \mathrm{~L}$ stainless steel tubes which are sealed by welding caps into each end. A zirconia insulator sleeve is located between the pellet column and the inside surface of the cladding. The cold nominal radial gap between the pellets and sleeve is 0.019 inch and the radial gap between the insulator sleeve and cladding is limited to 0.0005 inch.

A plenum at the top of the rod provides space for fission gases released from the pellets and for axial expansion of the fuel column. A coil spring loading a bearing spool is located in the plenum to maintain a compact fuel column. The fill gas is helium at 0.5-1.0 psig. The design of the fuel rods is shown in Phillip's Petroleum Company (PPCO) Drawing SPT-E-8743, Revision 1: See Drawing Section.

The design parameters for the fuel pellets and rods are shown in Table 2.1-1.

\subsection{TEST ASSEMBLY}

The seven fueled and two dummy rods are contained in a tube, called a basket, and are supported by a mounting plate attached to the bottom of the basket. Inserts are positioned between the fuel rod array and the inside surface of the tube to provide a $2.376 \mathrm{in.} \times 2.376 \mathrm{in}$. square flow channel for the full length of the fuel rods. Two egg 
TABLE 2.1-1 MECHANICAL DESIGN PARAMETERS FOR PBF FUEL RODS

Fuel Rod

Fuel Material

Urania Content, wt\%

$\mathrm{UO}_{2}-\mathrm{ZrO}_{2}-\mathrm{CaO}$

Zirconia Content, wt\%

30.6

Calcia Content, wt\%

62.3

Enrichment, wt\% ${ }^{235} \mathrm{U}$ in Total U

7.1

18.3

Pellet Diameter (in.)

$0.559 \pm .001$

Pellet Length (in.)

$1.100(\max$.

0.560 (min.)

Clad Material

304L Stainless Steel

Clad OD (in.)

0.75

Clad Thickness (in.)

0.027 (min.)

Zirconia Sleeve Thickness (in.)

0.048

Nominal Cold Helium Gap (in.)

0.019 (Radial)

Fuel Column Length (in.)

$36.000 \pm .036$ 
crate type spacers are located along the length of the fuel rods to maintain the fuel rod pitch. The design of the test assembly is shown in INC Drawing Nos. 402396, 402397 Sheets 1-3, 402398, and 402399. Drawings 402396, 402397 Sheet 1, and 402398 are included in the Drawing Section.

Each fuel rod is attached to the mounting plate by a bolt which extends through the mounting plate and through a captive plate and is screwed into the end fitting of the fuel rod. Projections on the end fittings of the fuel rods mate with slots in the mounting plate to prevent rotation of the fuel rods.

Al1 hardware components are fabricated from 304 or $304 \mathrm{~L}$ stainless stee 1 except the spacers which are fabricated from aluminum, and the basket inserts which are fabricated from Inconel Alloy 600.

The dummy rods consist of iron pellets clad with $304 \mathrm{~L}$ stainiess steel and have the same outside dimensions as the fuel rods. 


\subsection{OPERATING CONDITIONS}

The operating conditions for the test are shown in Table 3.0-1. The most important test condition which can be controlled is the inlet water temperature. The operating inlet temperature for the PBF Reactor coolant is approximately $130^{\circ} \mathrm{F}$.

M-3 loop heat exchanger calculations were made which conservatively predicted that loop inlet temperatures of $200^{\circ} \mathrm{F}$ are achievable at the calculated total heat generation of $231 \mathrm{~kW}$ with tube side and shell side flow rates of $100 \mathrm{gpm}$. The characteristics of the $M-3$ loop heat exchanger are shown in Figure 3.0-1.

Operation of the inlet temperature of the loop coolant to as close to $130^{\circ} \mathrm{F}$ as practicable is requested.

The test is scheduled to operate for one cycle only.

\subsection{SPECIAL REQUIREMENTS}

Orientation of the basket relative to the reactor is critical. Refer to INC Drawing No. 402396, Fuel Rod Test Hardware - PBF. Note the indexing toggle located at the end of the extension rod attached to the quick disconnect. With the assembly in the reactor, the toggle, when in the horizontal position, must point due south. 


\section{TABLE $3.0-1$ PBF TEST OPERATING CONDITIONS}

Reactor Power Level (MW) 175

Total Heat Generated, Fission and Gama (kW) 231

$\begin{array}{ll}\text { Operating Pressure (psig) } & 600\end{array}$

Inlet Temperature $\left({ }^{\circ} \mathrm{F}\right) \quad 200$

Loop Outlet Temperature (With Hot Spot Factor) $\left({ }^{\circ} \mathrm{F}\right)$

Flow Rates* (gpm)

Total 82

Basket Bore $\quad 57$

Basket - Pressure Tube Annulus 25

Average Flow Velocity (ft/sec) $\quad 11.0$

$\begin{array}{ll}\text { Pressure Drop Across Test Assembly (psi) } & 10\end{array}$

Maximum Heat Rating of Fuel Rod $(\mathrm{kW} / \mathrm{ft}) \quad 14.5$

Maximum Fuel Temperature Molten

Maximum Cladding Surface Temperature (With Hot Spot Factor) $\left({ }^{\circ} \mathrm{F}\right) \quad 300$

Saturation Temperature $\left({ }^{\circ} \mathrm{F}\right) \quad 488$

pH of Coolant $5.5-6.0$

* Calculated values. Flow tests will be run on test hardware. The results of the flow tests will be used for the in-reactor test. 
BNWL-B-75

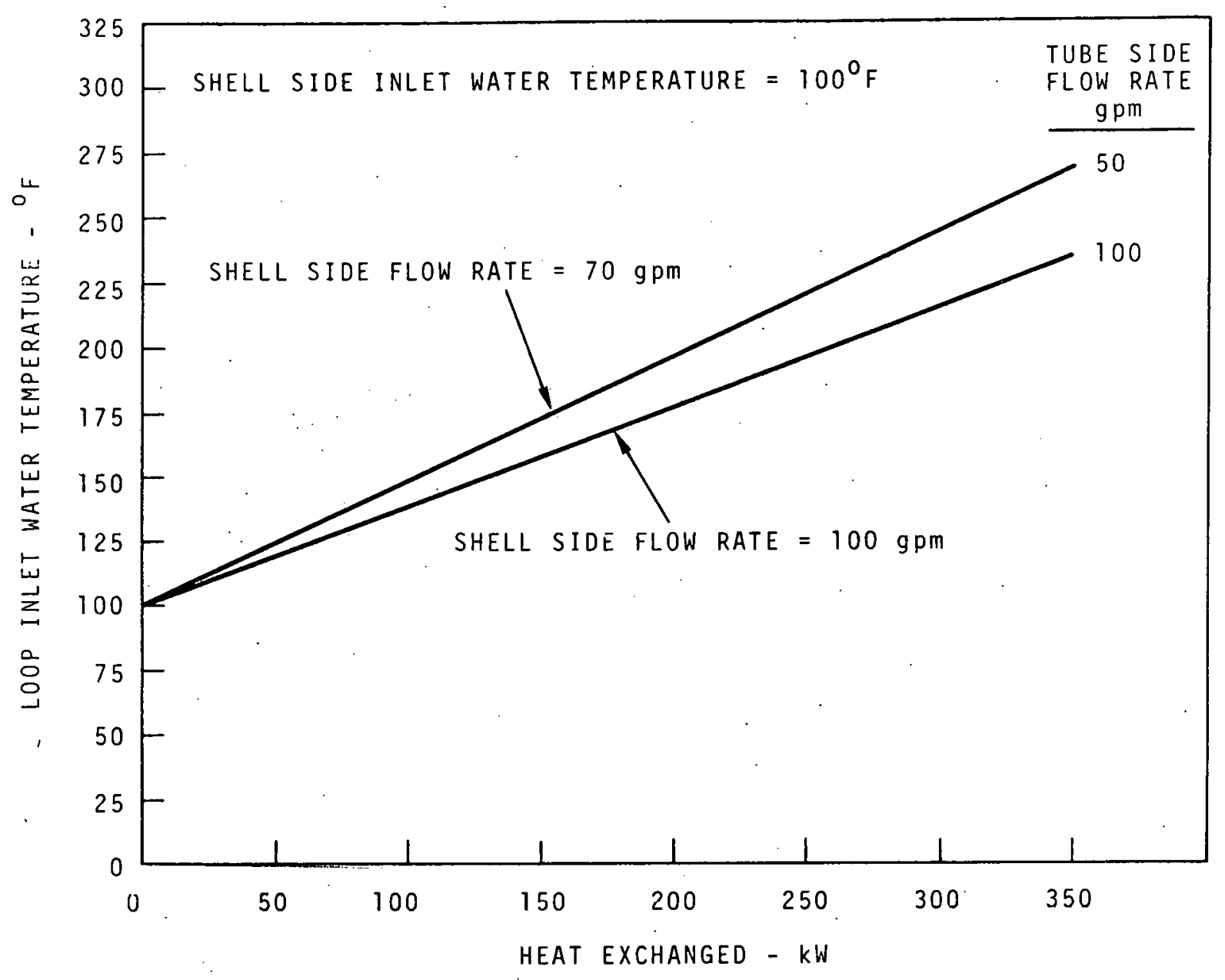

\footnotetext{
FIGURE 3.0-1 M-3 LOOP HEAT EXCHANGER CHARACTERISTICS FOR PBF TEST
} 


\subsection{MECHANICAL ANALYSIS}

5.1 EXTERNAL COLLAPSE PRESSURE, OPERATING PRESSURE, AND STRESS

5.1.1 Collapse and Operating Pressure

A tube is considered to be "free-standing" if yielding of the material does not occur at the maximum net external pressure and temperature conditions. An ideal tube will collapse when the net external pressure reaches: ${ }^{(1)}$

$$
P_{c r}=\frac{E}{4\left(T-v^{2}\right)}\left(\frac{h}{R}\right)^{3}
$$

where:

$$
\begin{aligned}
P_{C r} & =\text { Critical Collapse Pressure, psi } \\
E & =\text { Modulus of Elasticity }=28 \times 10^{6} \mathrm{psi} \\
\nu & =\text { Poisson's Ratio }=0.30 \\
\mathrm{~h} & =\text { Minimum Tube Wa11 Thickness, } 0.027 \text { inch } \\
\mathrm{R} & =\text { Tube Mean Radius, } 0.36325 \text { inch. } \\
P_{\mathrm{Cr}} & =\frac{28 \times 10^{6}}{4(1-0.09)}\left[\frac{0.027}{.36325}\right]^{3} \\
P_{C r} & =3158 \mathrm{psi}
\end{aligned}
$$

For a tube with less than ideal dimensions, collapse will occur at less than $P_{c r}$ due to effects of ovality. The equation from Reference 1 for this condition accounts for both tube ovality and yield strength. In this case, the critical collapse pressure for yielding becomes:

$$
P_{c r y}=1 / 2\left[A-\sqrt{A^{2}-4 B}\right]
$$


where:

$$
\begin{aligned}
A & \left.=\sigma_{y}\left(\frac{h}{R}\right)+\left[1+6 \frac{U_{0}}{R} \frac{R}{h}\right] P_{c r} \quad 2\right) \\
\sigma_{y} & =Y i e l d \text { Strength }=40,000 \text { psi } \\
h / R & - \text { as previously stated in Equation (1) } \\
U_{0} & =1 / 4\left(I D_{\text {max. }}-I D_{\text {min. }}\right) \\
P_{c r} & =\text { That value determined by Equation (1), and } \\
B & =\sigma_{y} \frac{h}{R} P_{c r} \\
A & =(40,000)\left(\frac{.027}{.36325}\right)+\left(1+\frac{1.5(.002)}{0.027}\right) 3158 \\
A & =6482 \\
B & =(40,000)\left(\frac{.027}{.36325}\right) 3158 \\
B & =9.39 \times 10^{6} \\
P_{C r} & =1 / 2\left[6482-\sqrt{42.02 \times 10^{6}-37.56 \times 10^{6}}\right. \\
P_{C r} & =2175 \mathrm{psi} .
\end{aligned}
$$

A maximum loop operating pressure of 600 psi was selected which provides a safety factor of 3.6 .

\subsubsection{Pressure Stress}

The hoop stress is determined from the equation:

$$
\sigma_{\theta}=\frac{P_{0} R}{h}
$$

The bending stresses due to ovality are calculated from:

$$
u_{b}= \pm v_{\theta}\left[\begin{array}{ll}
G \frac{U_{0}}{h} & \left.\frac{P}{\left(P_{c r}-P_{0}\right.}\right)
\end{array}\right]
$$




$$
\text { where: } \begin{aligned}
\sigma_{\theta} & =\text { Hoop stress, psi; } \sigma_{b}=\text { Bending stress, psi } \\
p_{0} & =\text { External pressure, psi } \\
\sigma_{\theta} & =(600)(.36325) /(.027)=8100 \mathrm{psi} \\
\sigma_{b} & = \pm(8100)(.111)(1.234)= \pm 1100 \mathrm{psi} \\
\sigma_{\theta} & +\sigma_{b}=7100 \pm 1100 \mathrm{psi}
\end{aligned}
$$

\subsection{CLADDING THERMAL STRESSES}

The thermal stresses are directly proportional to the temperature gradient across the cladding wall. The thermal stresses at the surface may be written as:

$$
\sigma_{\theta}= \pm \frac{E \alpha \Delta t}{2(1-v)}
$$

where:

$$
\begin{aligned}
E & =\text { Modulus of Elasticity }=28 \times 10^{6} \mathrm{psi} \\
\alpha & =\text { Coefficient of Thermal Expansion }=8.0 \times 10^{-6} \mathrm{in} / \mathrm{in} /{ }^{\circ} \mathrm{F} \\
\Delta t & =\text { Temperature Gradient Across Cladding Wal1, } 73^{\circ} \mathrm{F} 014.5 \mathrm{~kW} / \mathrm{ft} \\
\nu & =\text { Poisson's Ratio }=0.30 \\
\sigma_{\theta} & =\text { Hoop Stress, psi } \\
\sigma_{\theta} & = \pm \frac{\left(28 \times 10^{6}\right)\left(8.0 \times 10^{-6}\right)(73)}{(2)(0.70)} \\
\sigma_{\theta} & = \pm 11,700 \mathrm{psi}
\end{aligned}
$$

\subsection{COMBINED STRESSES}

The maximum stress occurs at the inner surface of the cladding and results from a combination of the hoop and thermal stresses. The results 
below are at a heat rating of $14.5 \mathrm{~kW} / \mathrm{ft}$, an external pressure of 600 psi, and an internal pressure of 0 psi.

$$
\text { Maximum operating stress, } \begin{aligned}
\sigma_{m} & =8100+1100+11,700 \\
\sigma_{m} & =20,900 \text { psi }
\end{aligned}
$$

This operating stress is $52 \%$ of the yield stress of 40,000 psi.

\subsection{INTERNAL FISSION GAS PRESSURE}

For each megawatt day (MWd) of burnup, $1.3 \times 10^{-3} \mathrm{gm}$-mols of $\mathrm{Kr}+\mathrm{Xe}$ are formed. Using this data and assuming all of the gas generated is released from the fuel, the total mols of $\mathrm{Kr}+\mathrm{Xe}$ can be calculated:

Tons of $U$ per fuel rod:

$$
\begin{aligned}
& \frac{238 \mathrm{gmU}}{6.04 \times 10^{23} \text { atom } \mathrm{U}} \times \frac{41.6 \times 10^{20} \text { atoms } \mathrm{U}}{\mathrm{cm}^{3} \text { fuel }} \times \frac{\pi}{4}(.559)^{2}(36)(16.34) \frac{\mathrm{cm}^{3} \text { fuel }}{\text { rod }} \times \frac{\mathrm{MT}}{10^{6} \mathrm{gm} \mathrm{U}} \\
& =2.37 \times 10^{-4} \text { Metric tons U/rod }
\end{aligned}
$$

Heat generated per fuel rod:

$$
=\frac{14.5 \mathrm{~kW} \times 3 \mathrm{ft} \mathrm{MW}}{1.32 \mathrm{ft} \mathrm{rod} 1000 \mathrm{~kW}}=0.0330 \frac{\mathrm{MW}}{\mathrm{Rod}}
$$

Burnup after one cycle, assume 30 days

Burnup $=0.0330 \frac{\mathrm{MW}}{\operatorname{Rod}} \frac{\mathrm{Rod}}{2.37 \times 10^{-4} \mathrm{MT}} \times 30$ Days

Burnup $=4200 \frac{\text { MWd }}{\text { MTM }}$

Total $\mathrm{Kr}+\mathrm{Xe}=1.31 \times 10^{-3} \frac{\mathrm{gm}-\mathrm{mols}}{\mathrm{MWd}} \times 2.37 \times 10^{-4} \frac{\mathrm{MT}}{\mathrm{Rod}} \times 4200 \frac{\mathrm{MWd}}{\mathrm{MT}}$

Total $\mathrm{Kr}+\mathrm{Xe}=1.3 \times 10^{-3} \mathrm{gm}-\mathrm{mols}$ of $\mathrm{Kr}$ and $\mathrm{Xe} / \mathrm{rod}$ 
Internal Pressure:

Assume that all fission gas is collected in the plenum and is at the average temperature of the coolant.

$$
\begin{aligned}
P V & =n R T \\
n & =1.3 \times 10^{-3} \mathrm{gm}-\mathrm{mols} \\
R & =40.6 \frac{\mathrm{in}-1 \mathrm{~b}}{\mathrm{gm}-\mathrm{mol}{ }^{\circ} \mathrm{R}}
\end{aligned}
$$

Volume: (V)

Annulus between pellet column and insulator sleeve ID

$$
\frac{\pi}{4}\left(.5975^{2}-.570^{2}\right)(36+2.5)=0.971 \mathrm{in}^{3}
$$

Annulus between bearing spool and cladding ID

$$
\frac{\pi}{4}\left(.691^{2}-.562^{2}\right)(2)=0.254 \mathrm{in}^{3}
$$

Cavity in bearing spool

$$
\frac{\pi}{4}\left(.469^{2}\right)(4.312)=0.745 \mathrm{in}^{3}
$$

Free volume in spring chamber

$$
\frac{\pi}{4}\left(.691^{2}\right)(4.250)-\frac{.087 \text { lbs } \text { in }^{3}}{\text { spring } .280 \text { 1bs }}=0.972 \mathrm{in}^{3}
$$

Total volume $=0.971+0.254+0.745+0.972=2.942$ in $^{3}$

Assume temperature of coolant is $2250^{\circ} \mathrm{F}$ or $710^{\circ} \mathrm{R}$

$$
\begin{aligned}
& P=\frac{\left(1.3 \times 10^{-3}\right)(40.6)(710)}{2.942} \\
& P=13 \text { psi from fission gas }
\end{aligned}
$$




\subsection{HEAT GENERATION}

\subsection{FISSION HEAT GENERATION}

The fission heat generation calculations for the test assembly with seven fueled rods and two dummy rods were performed with the THERMOS and the 2DB computer codes. $(2,3)$ The calculations and the heat generation results obtained ${ }^{(4)}$ from the computer runs were based on experimental flux data obtained from the irradiation of GEH-10-101-148 in the M-3 loop during cycle 85 .

The thermal flux in the M-3 loop during cycle 112 could be approximately $10 \%$ less than during cycle $85^{(5)}$. The heat generation results which were based on cycle 85 were reduced $8 \%$ to compensate for the expected lower flux in the M-3 loop during cycle 112. Based on heating rates normalized to cycle 112, the predicted maximum linear fission heat rating in $\mathrm{kW} / \mathrm{ft}$ for each fuel rod is shown in Figure 6.1-1.

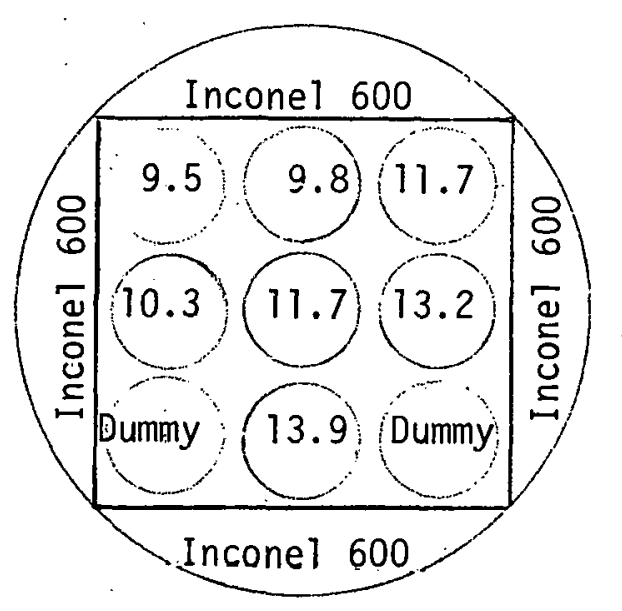

Reactor 
The total fission power in the assembly is based on an axial peak to average factor of 1.32 and an active fuel length of three feet.

Total Fission Power $=\frac{[9.5+9.8+11.7+10.3+11.7+13.2+13.9]}{1.32}$ (3)

Total Fission Power $=182 \mathrm{~kW}$

\subsection{GAMMA HEAT GENERATION}

The gamma heat generation is based on an average gamma heating rate of $1.0 \mathrm{watt} / \mathrm{gm}$ in the active region. The dummy rods, fuel, insulating sleeve, cladding, basket, and pressure tube were considered in the calculation. The results are summarized in Table $6.2-1$ and the detailed calculations are presented in Appendix A.

\begin{tabular}{|c|c|c|c|}
\hline Component & $\begin{array}{c}\text { Component } \\
\gamma \text { Heat Rating } \\
\mathrm{kW} \\
\end{array}$ & $\begin{array}{l}\text { Number of } \\
\text { Components } \\
\text { per Test Assembly }\end{array}$ & $\begin{array}{c}\text { Total } \\
\gamma \text { Heat Rating } \\
\mathrm{kW}\end{array}$ \\
\hline Dummy Rods & 1.1 & 2 & 2.2 \\
\hline Fue 1 & 0.8 & 7 & 5.6 \\
\hline Sleeve & 0.3 & 7 & 2.1 \\
\hline Cladding & 0.3 & 7 & 2.1 \\
\hline Basket & 13.9 & 1 & 13.9 \\
\hline Pressure Tube & 22.6 & 1 & 22.6 \\
\hline Total & & & 48.5 \\
\hline
\end{tabular}

TABLE 6.2-1. Gamma Heat Generation Rates for PBF Test Assembly 


\subsection{TEST ASSEMBLY AND FUEL ROD HEAT GENERATION}

\subsubsection{Test Assembly}

The total heat generated in the test assembly is the sum of the gamma heat generated in the fuel and hardware components and the fission heat generated in the fuel.

Total Heat Generated = Gamma + Fission

Iotal Heat Generated $=48.5+182=\underline{230.5 \mathrm{~kW}}$

\subsubsection{Maximum Linear Heat Rating in Highest Powered Fuel Rod}

The maximum linear heat rating occurs in the fuel rod nearest the reactor and is the sum of the gamma and fission heating in the rod. The gamma heating rates are from Table 6.2-1; the fission heating rate is from Figure 6.1-1.

Gamma $=\frac{(0.8+0.3+0.3)(1.32)}{3}=0.6 \mathrm{~kW} / \mathrm{ft}$

Fission $=13.9 \mathrm{~kW} / \mathrm{ft}$

Maximum Linear Heat Rating $=i 3.9+0.6=14.5 \mathrm{~kW} / \mathrm{ft}$ 


\subsection{THERMAL-HYDRAULIC ANALYSIS}

\subsection{HYDRAULIC CHARACTERISTICS}

The pressure drop versus flow rate characteristics for the basket bore and for the basket-pressure tube annulus are presented in Figure 7.1-1 and are summarized below for the loop operating conditions.

\section{Flow Rate} gal/min.

Basket Bore 57

Basket-Pressure Tube Annulus 25

Tota 1

82

The pressure drop across the assembly of $10 \mathrm{psi}$ is calculated for these conditions. The calculations were made using the equation shown in Appendix B.

\subsection{FUEL ROD SURFACE AND COOLANT TEMPERATURES}

The fuel rod surface and coolant temperatures are summarized below and the detailed calculations are presented in Appendix B.

$\begin{array}{lcc} & \text { Calculated } & \text { Adjusted } \\ \text { Loop Inlet, }{ }^{\circ} \mathrm{F} & & 200 \\ \text { Loop Outlet, }{ }^{\circ} \mathrm{F} & 221 & 230 \\ \text { Basket Outlet, }{ }^{\circ} \mathrm{F} & 225 & 234 \\ \text { Surface Temperature (Max.) }{ }^{\circ} \mathrm{F} & 272 & 300 \\ \text { Saturation Temperature (d } 600 \mathrm{psi} & & 488 \\ \text { Surface Heat Flux, (Maximum), } & 251,000: \\ \text { Btu/hr-ft }\end{array}$


BNWL-B-75

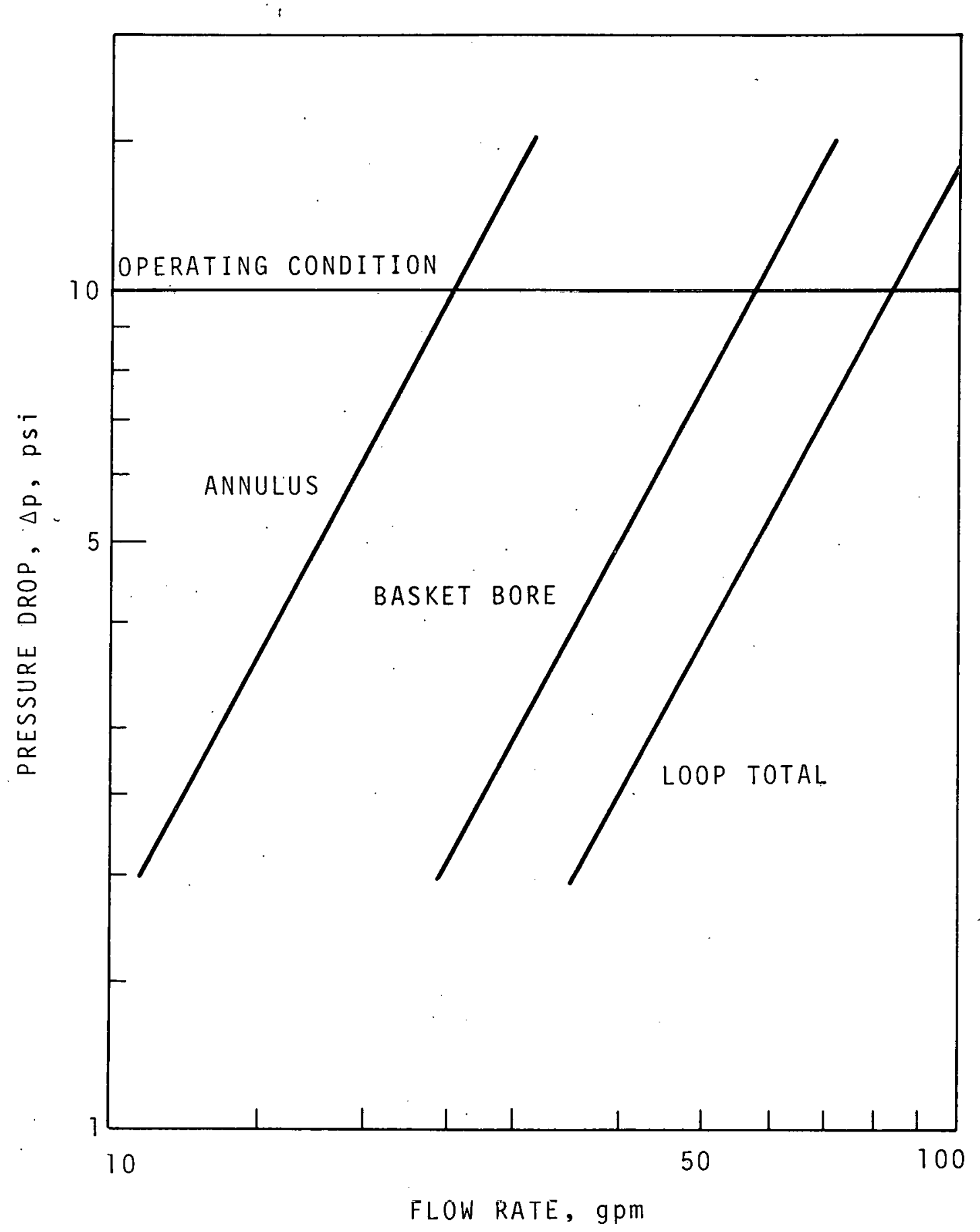

FIGURE 7.1-1 HYDRAULIC CHARACTERISTICS FOR PBF TEST IN THE $M-3$ LOOP 


\subsection{FUEL THERMAL ANALYSIS}

The maximum design linear heat rating for the fuel is $14.5 \mathrm{~kW} / \mathrm{ft}$.

Thermal analyses of the fuel were performed to determine the heat rating at which incipient fuel melting would occur and the extent of fuel melting at $14.5 \mathrm{~kW} / \mathrm{ft}$.

Two cases were considered to determine the linear heat rating at which incipient fuel melting $\left(4260^{\circ} \mathrm{F}\right)$ would sccur:

(1) The fuel pellets crack and fill the gap between the pellets and insulator sleeve.

(2) The fuel pellets do not crack but thermally expand $2-1 / 2 \%$ leaving a radial gap filled with helium between the pellets and insulator sleeve.

The calculated linear heat rating at which incipient melting occurs is $12.0 \mathrm{~kW} / \mathrm{ft}$ for both cases. A plot of fuel centerline temperatures versus linear heat rating is shown in Figure 7.3-1 for case 1 .

In case 2 , the transfer of heat by both conduction and radiation was considered. The combined conduction and radiation heat transfer coefficient is $275 \mathrm{Btu} / \mathrm{hr}-\mathrm{ft}^{2}{ }^{\circ} \mathrm{F}$. The thermal conductivity for the uncracked fuel (case 2) is significantly higher than the thermal conductivity for the cracked fuel (case 1).

For the extent of fuel melting at $14.5 \mathrm{~kW} / \mathrm{ft}$, the calculations predict that $54 \%$ of the fuel pellet radius will be above the melting point. This condition will produce a combination of the solid and liquid phase and the liquid phase. 


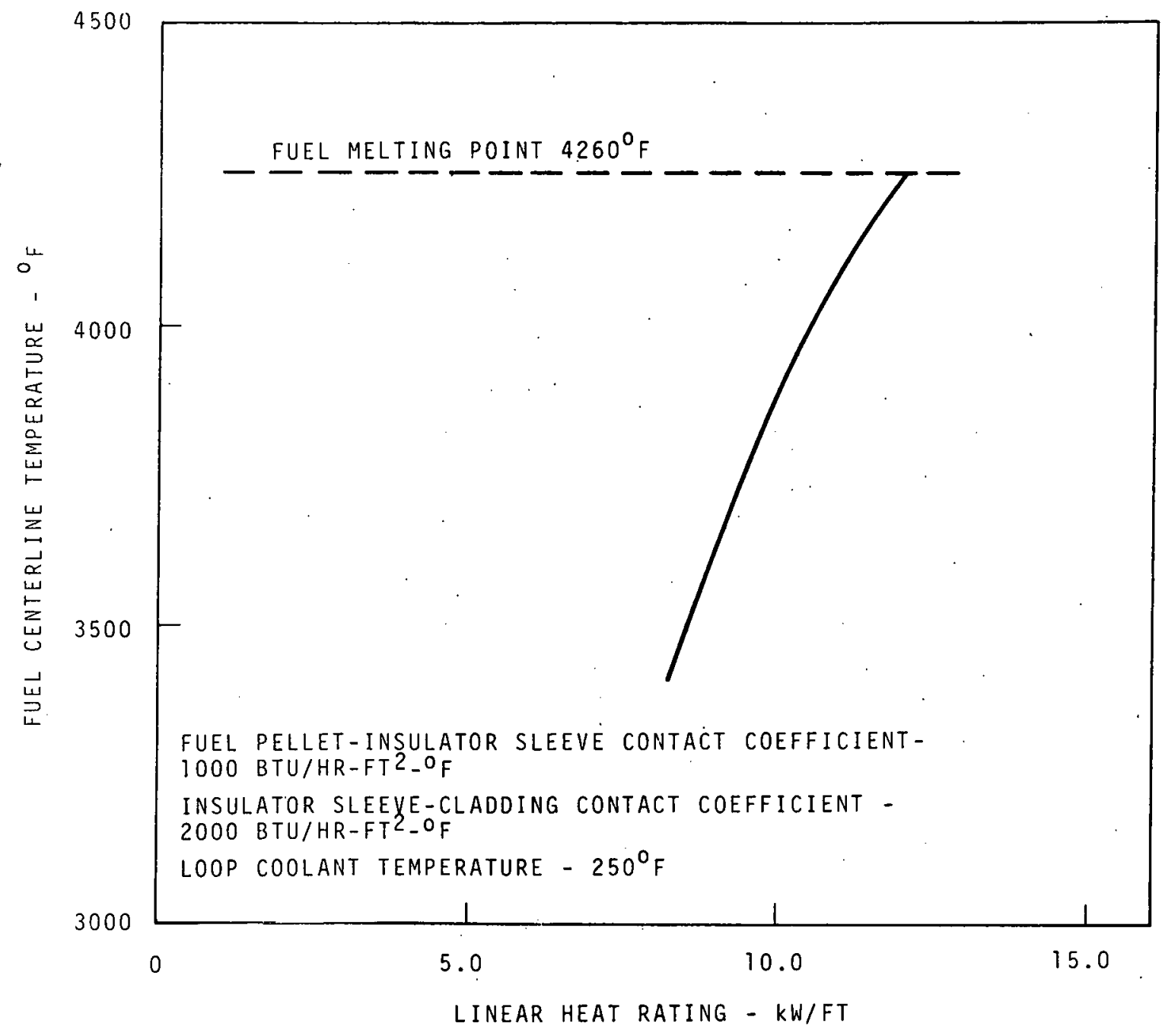

FIGURE 7.3-1. FUEL CENTERLINE TEMPERATURE - PBF FUEL IN ETR 
The thermal conductivities of the stainless steel cladding, the $\mathrm{ZrO}_{2}$ insulator sleeve, and the cracked and uncracked fuel pellets were taken from Reference 6 . Contact coefficients of $1000 \mathrm{Btu} / \mathrm{hr}-\mathrm{ft} \mathrm{t}^{2}{ }^{\circ} \mathrm{F}$ for the cracked fuel-insulator interface and of $2000 \mathrm{Btu} / \mathrm{hr}-\mathrm{ft}{ }^{2}{ }^{\circ} \mathrm{F}$ for the insulator-cladding interface were obtained from R. P. Watkins ${ }^{(7)}$ of INC. No credit was taken for fuel restructuring.

The THERMOS ${ }^{(2)}$ code was used to calculate the thermal flux depression across the fuel. The CHEATI ${ }^{(8)}$ code was used to calculate the temperature distribution across the fuel rod.

The elongation in the fuel column length at temperatures immediately below the melting point is $3 \%$. (9) This elongation would cause a nominal 1.08 inch increase in fuel column length. The remaining plenum spring deflection to solid height is a nominal 1.57 inch. Thus, sufficient clearance is available for fuel column elongation. 


\subsection{HAZARDS ANALYSIS}

\subsection{FUEL ROD-TO-FUEL ROD CONTACT}

The pitch of the rods in the $3 \times 3$ array produces a compact bundle of fuel rods with a nominal clearance between adjacent rods of 0.040 inch. When consideration is given to tolerances, initial non-straightness of rods, and bowing as a result of the radial flux gradient across the fuel rods, the possibility of adjacent rods touching cannot be discounted.

An analysis was made to determine the effect on the cladding temperature of contacting fuel rods. A quarter section of the cladding cross section was divided into 9 nodes of $10^{\circ}$ each. The surface heat transfer coefficient for two adjacent nodes was set equal to essentially zero to simulate fuel rod contact. A $20^{\circ}$ section which corresponds to a circumferential distance of 0.132 inch is considered a conservative distance over which contacting rods would restrict the flow of heat. The heat transfer coefficient for the remaining surface area was assumed to be $5000 \mathrm{Btu} / \mathrm{hr}-\mathrm{ft}^{2}-{ }^{\circ} \mathrm{F}$. The linear heat rating was 14.5 $\mathrm{kW} / \mathrm{ft}$.

The results of the analys is predicted local maximum cladding temperatures of $560^{\circ} \mathrm{F}$ and maximum surface temperatures of $525^{\circ} \mathrm{F}$. A surface temperature of $525^{\circ} \mathrm{F}$ is $37^{\circ} \mathrm{F}$ above the saturation temperature of $488^{\circ} \mathrm{F}$. Localized boiling can be expected.

The temperature gradients across the cladding and circumferentially along the cladding at the location of contact increase, which causes 
an increase in the cladding thermal stress. An order of magnitude stress calculation was made which predicts that the stress in the cladding would be greater than yield and less than the ultimate stress. Yielding of the cladding would be restricted by the insulating sleeve.

Stainless steel clad fuel rods have failed under high stress conditions because of stress-assisted intergranular corrosion attack. (10) Because of the short duration of this test (one cycle), stressassisted intergranular corrosion is not expected to cause cladding failure.

\subsection{FUEL ROD FAILURE}

Intentionally defected $\mathrm{UO}_{2}$ pellet and vipac fuels have been irradiated under conditions which produce fuel melting or near melting in the ETR P-7 loop, $(11-14)$ the Fuel El ement Rupture Test Facility (FERTF) in PRTR, (15) and in the X-6 loop of the NRX Reactors in Canada. (16) An intentionally defected Zircaloy-clad element containing Al-Pu alloy fuei was successfully irradiated in the ETR P-7 loop. (11) Intentionally defected mixed-oxide fuel rods have been successfully irradiated in the ETR M-3 loop. (17)

In Big Rock Point Reactor over a period of three years, 145 known failures were known to have occurred. (10) Failures were gross and exposed large surfaces of $\mathrm{UO}_{2}$ to the reactor water. In a number of failures there was significant loss of $\mathrm{UO}_{2}$ to the reactor environment. 
During this period of time fuel operated with a large volume of the $\mathrm{UO}_{2}$ molten. Reference (10) did not state whether or not rods operating with molten cores had failed. The authors concluded that fuel failures were more of an economic problem than a safety problem.

In view of the operating experience with failed fuel rods in both test and commercial reactors, fuel failure is not considered a safety problem for this test.

\subsection{QUALITY ASSURANCE}

Quality assurance documentation will be submitted in another report. 


\subsection{DRAWINGS OF PBF FUEL ROD AND TEST ASSEMBLY}









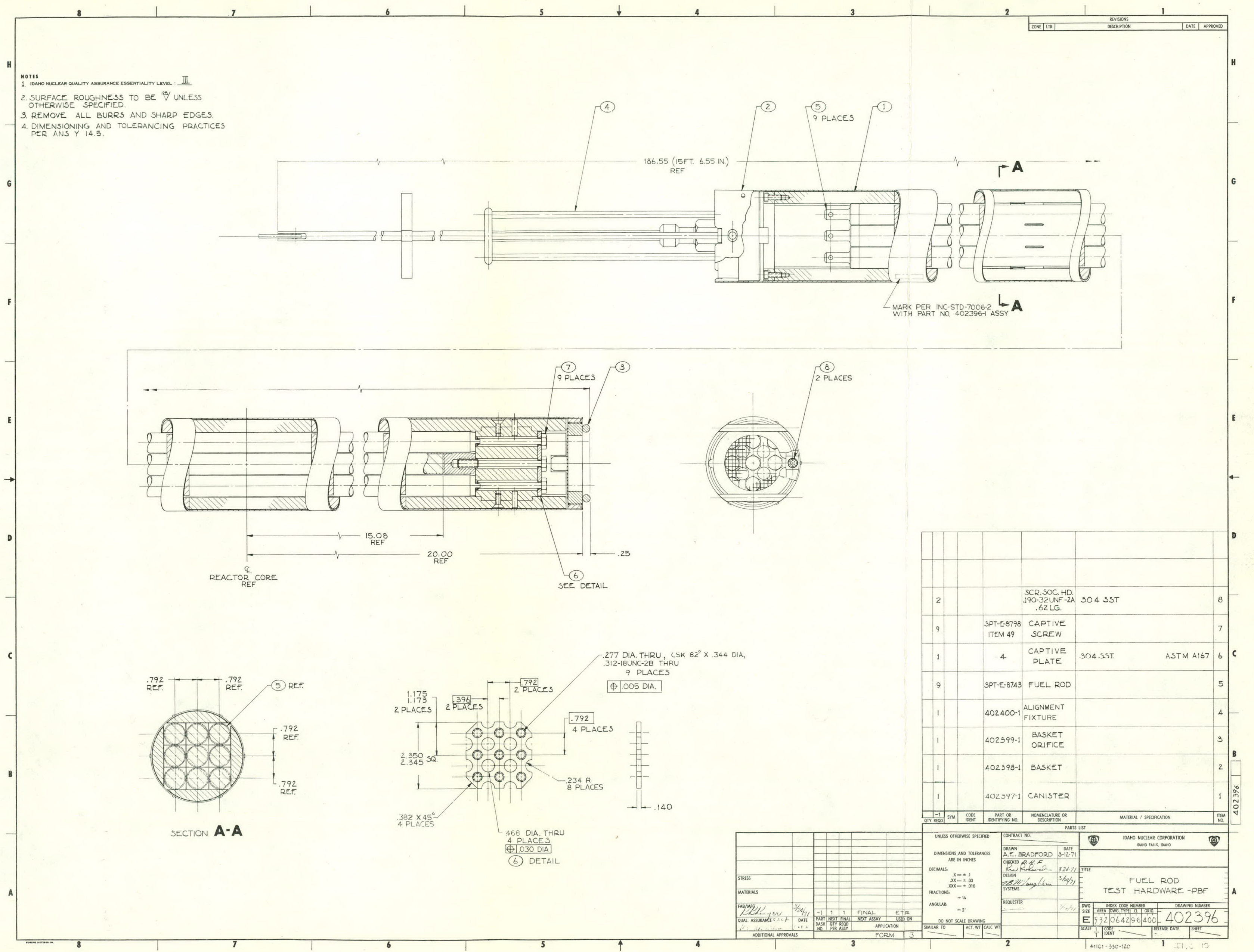




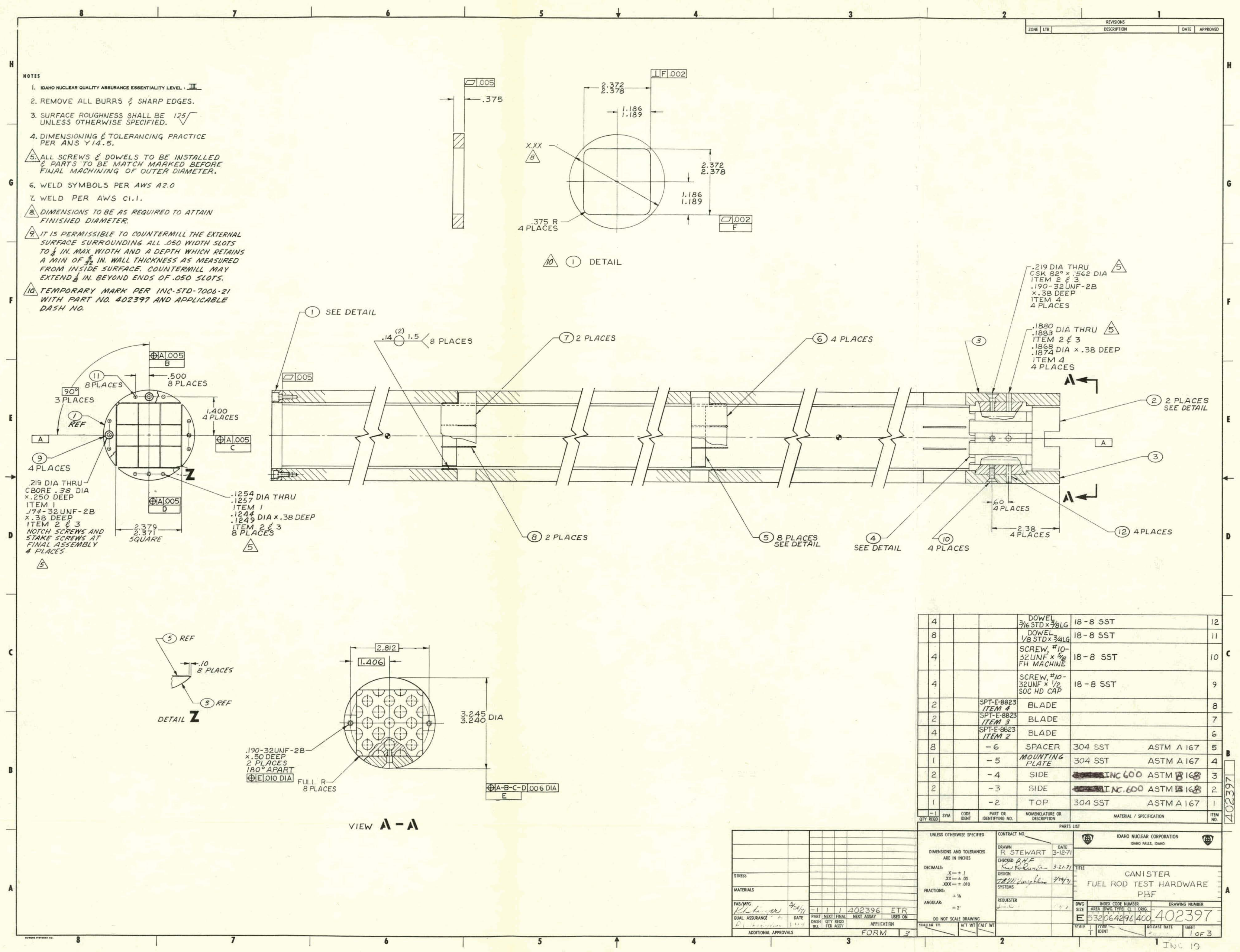




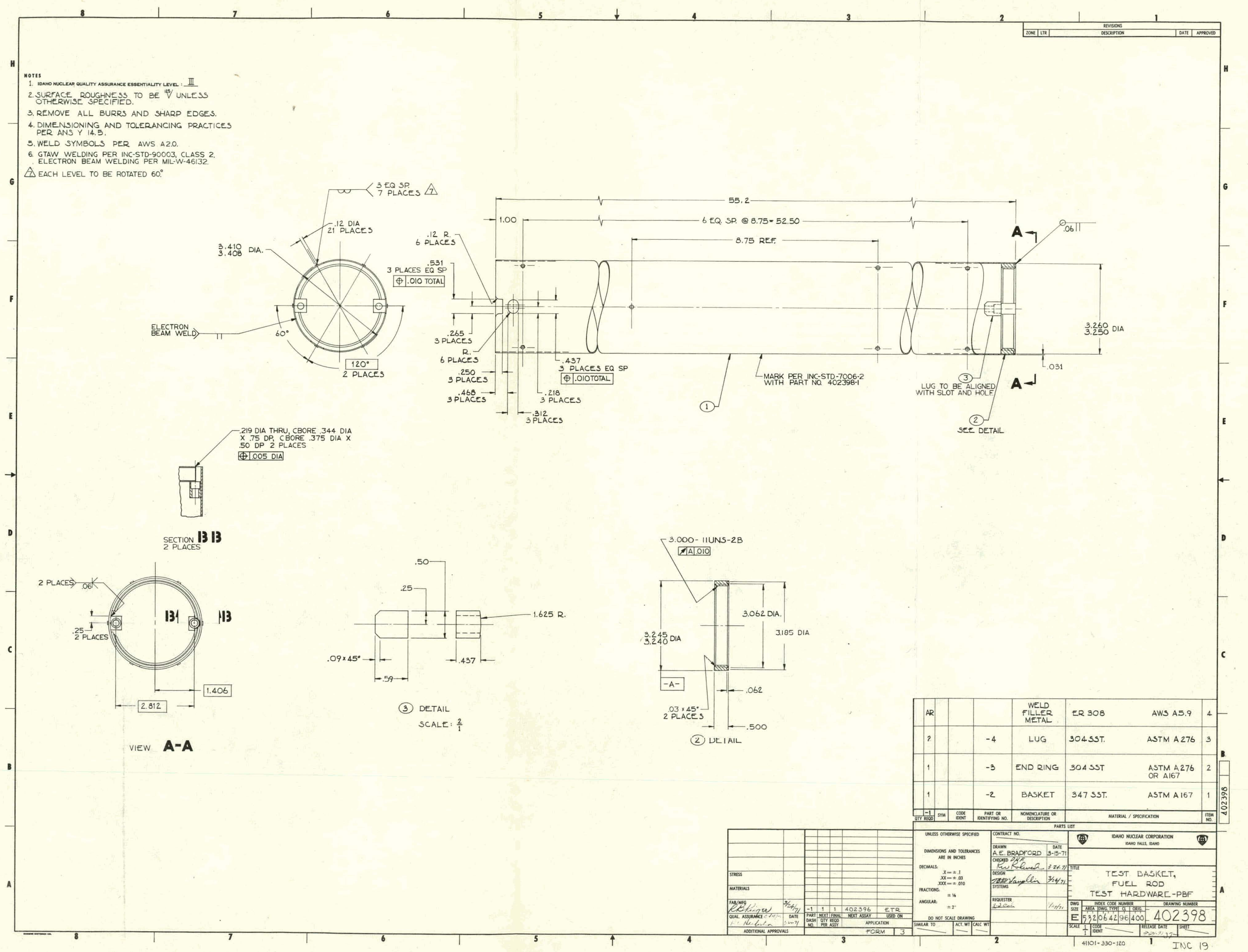




\section{REFERENCES}

1. S. Timoshenko. Strength of Materials, Part 2, Third Edition, D. Van Nostrand, New York, 1956. pp. 186-190.

2. D. R. Skeen and L. J. Page. THERMOS/Battelle: The Battelle Version of The THERMOS Code, BNWL-516. Battelle-Northwest, Richland, Washington, September 1967.

3. W. W. Little, Jr., and R. W. Hardie. 2DB User's Manual, BNWL-831, REV 1 , August 1969.

4. Letter, J.W. Kutcher to R. K. Marshall. Subject: Physics Calculations for Irradiation of PRF Fuel Rods in the ETR M-3 Loon. Apri1 8, 1971.

5. Letter, J. D. Berger (BNW) to R. E. 0swald (INC). INC-19 (PBF Test) M-3 Loop Flux Requirements. April 1, 1971

6. R. P. Wadkins. Parametric Thermal Analysis of PBF Hot Fuel Rod for 1.3-MSEC POWER BURST, Report No. A-35, March 28, 1969. Phillips Petroleum Co., Idaho Falls, Idaho.

7. Telephone conversation, R. K. Marshall and R. P. Wadkins, March 23, 1971.

8. CHEATI, Undocumented Hanford Site Computer Code.

9. A. D. Feith, R. A. Hein, R. E. Latta. Thermal Property Data for $62 \mathrm{ZrO}_{2}$ $30 \mathrm{UO}_{2}-8 \mathrm{CaO}$ at High Temperatures, GESP-4T. General Electric Missile and Space Division, Cincinnati, Ohio. 1968.

10. G. J. Walke, R. W. Sinderman, C. E. Axtell (Consumers Power Mich.). "The Effects of Failed Fuel on the Operation of a Commercial BWR Plant." Trans. Am. Nucl. Soc. vol. 13, 1970. p. 165.

11. M. D. Freshley and F. E. Young. Proposal for Rupturing an Al-Pu Seven-Rod Cluster (GEH-11-5) in the ETR 3x3P7 Facility, HW-67366, Nov. 8, 1960.

12. L. A. Pember. Proposal to Irradiate a Defect Test, GEH-12-38, BNWC-52, March 13, 1965.

13. F. E. Panisko and L. A. Pember. Proposal to Irradiate a Defect Test, GEH-12-39, BNWL-CC-433, Nov. 18, 1965.

14. M. D. Freshley, Proposal to Irradiate an Intentionally Defected U0 Element in the ETR P-7 LoOp: GEH-12-40, BNWL-CC-1181, Apri1 24, 1967.

15. M. D. Freshley and F. E. Panisko, The Irradiation Behavior of $\mathrm{UO}_{2}-\mathrm{PuO}_{2}$ Fuels in PRTR, BNWL-366, March 1967. 
16. D. H. Locke. "Defected Zircaloy Fue1," Nuclear Engineering International, August 1968, pp. 648-652.

17. C. R. Hann, T. B. Burley, and M. D. Freshley, Proposal to Irradiate Intentionally Defected Mixed-0xide Fuel Rods in the ETR-M-3 Loop Facility, The $23 \mathrm{~kW} / \mathrm{ft}$ Test Series - (BNW-5-1 through -6), BNWL-CC-2445, February 10, 1970 . 
APPENDIX A

GAMMA HEAT GENERATION CALCULATIONS 


\section{GAMMA HEAT GENERATION CALCULATIONS}

GAMMA HEAT GENERATION

The gamma heat generation is based on an average gamma heating rate of 1.0 watt/gm.

Dummy Rods

$$
\begin{aligned}
\text { Dia } & =0.559, \text { Active length }=36 " \\
& =\frac{\pi}{4}(.559)^{2}(36) \mathrm{in}^{3}(7.92) \frac{\mathrm{gm}}{\mathrm{cm}^{3}}(16.39) \frac{\mathrm{cm}^{3}}{\mathrm{in}^{2}}(.001) \frac{\mathrm{kW}}{\mathrm{gm}} \\
& =1.12 \mathrm{~kW} / \mathrm{rod}
\end{aligned}
$$

Fuel $\left(\mathrm{UO}_{2}-\mathrm{ZrO}_{2}-\mathrm{CaO}\right)$

$$
\begin{aligned}
& \text { Dia }=559^{\prime \prime}, \text { Active length }=36^{\prime \prime} \\
& \frac{\pi}{4}(.559)^{2}(36) \mathrm{in}^{3}(5.82) \frac{\mathrm{gm}}{\mathrm{cm}^{3}}(16.34) \frac{\mathrm{cm}^{3}}{\mathrm{in}^{3}}(.001) \frac{\mathrm{kW}}{\mathrm{gm}} \\
& =0.84 \mathrm{~kW} / \mathrm{rod}
\end{aligned}
$$

Insulating Sleeve $\left(\mathrm{ZrO}_{2}\right)$

$$
\begin{aligned}
& \text { OD }=0.694^{\prime \prime} \\
& I D=0.598^{\prime \prime} \\
& \text { Active 1ength }=36^{\prime \prime} \\
& \qquad \frac{\pi}{4}\left(.694^{2}-.598^{2}\right)(36) \mathrm{in}^{3}(5.6) \frac{\mathrm{gm}}{\mathrm{cm}^{3}}(16.39) \frac{\mathrm{cm}^{3}}{\mathrm{in}^{3}}(.001) \frac{\mathrm{kW}}{\mathrm{gm}} \\
& =0.32 \mathrm{~kW} / \mathrm{rod}
\end{aligned}
$$

Cladding (304SS)

$$
\begin{aligned}
& O D=.755^{\prime \prime} \\
& I D=.695^{\prime \prime} \\
& \text { Active length }=36^{\prime \prime} \\
& \qquad \frac{\pi}{4}\left(.755^{2}-.695^{2}\right)(36) \mathrm{in}^{3}(7.92) \frac{\mathrm{gm}}{\mathrm{cm}^{3}}(16.39) \frac{\mathrm{cm}^{3}}{\mathrm{in}^{3}}(.001) \frac{\mathrm{kW}}{\mathrm{gm}} \\
& =0.32 \mathrm{~kW} / \mathrm{rod}
\end{aligned}
$$


Basket (304 SS)

$O D=3.313^{11}$

Inside $($ Square $)=2.375^{\prime \prime} \times 2.375^{\prime \prime}$

Active Length $=36^{\prime \prime}$

$$
\frac{\pi}{4}\left(3.313^{2}\right)-\left(2.375^{2}\right) \quad(36) \mathrm{in}^{3}(7.92) \frac{\mathrm{gm}}{\mathrm{cm}^{3}}(16.39) \frac{\mathrm{cm}^{3}}{\mathrm{in}^{3}}(.001) \frac{\mathrm{kW}}{\mathrm{gm}}
$$

$=13.93 \mathrm{~kW}$

Pressure Tube $(2 r-2)$

$O D=4.391^{\prime \prime}$

ID $=3.441^{\prime \prime}$

Active length $=36^{\prime \prime}$

$$
\frac{\pi}{4}\left(4.391^{2}-3.441^{2}\right)(36) \mathrm{in}^{3}(6.55) \frac{\mathrm{gm}}{\mathrm{cm}^{3}}(16.39) \frac{\mathrm{cm}^{3}}{\mathrm{in}^{3}}(.001) \frac{\mathrm{kW}}{\mathrm{gm}}
$$

$=22.58 \mathrm{~kW}$ 
BNWL $-B-75$

APPENDIX B

THERMAL-HYDRAULIC CALCULATIONS 
APPENDIX B

THERMAL-HYDRAULIC CALCULATIONS

\section{HYDRAULIC CHARACTERISTICS}

The pressure drop versus flow rate characteristics for the basket-bore and basket-pressure tube annulus were calculated according to the following equation:

where:

$$
\Delta P=\frac{\rho V^{2}}{2 g(144)} \frac{f l}{D_{e}}+K_{e x p}+K_{\text {cont }}
$$

$$
\begin{aligned}
& \Delta P=\text { Pressure drop, psi } \\
& \rho=\text { Density of water, } 1 \mathrm{bs} / \mathrm{ft}^{3} \\
& g=32.2 \mathrm{ft} / \mathrm{sec}^{2} \\
& f=\text { Friction factor } \\
& 1 \text { = Length of flow channel, ft } \\
& D_{e}=\text { Equivalent diameter, } \mathrm{ft} \\
& K_{\text {exp }}, K_{\text {cont }} \text { - Expansion and contraction loss coefficients } \\
& V=\text { Velocity, } f t / s e c
\end{aligned}
$$

The resuits of the calculations are presented in Figure 7.T-1.

\section{FUEL ROD SURFACE AND COOLANT TEMPERATURES}

\section{Bulk Water Temperature Rise}

$$
\begin{aligned}
\Delta t_{b}= & \frac{q_{C}}{w C_{p^{\rho}}} \\
\Delta t_{b} & =\text { Bulk water temperature rise } \\
q_{C} & =\text { Heat transferred to coolant }
\end{aligned}
$$




$$
\begin{aligned}
& w=\text { Flow rate, } 1 \mathrm{~b} / \mathrm{hr}(\text { loop flow rate }=75 \mathrm{gpm}) \\
& C_{\mathrm{p}}=\text { Specific heat of water at } 600 \mathrm{psi} \text { and } 225^{\circ} \mathrm{F} \\
& \rho=\text { Density of water at } 600 \mathrm{psi} \text { and } 225^{\circ} \mathrm{F} \\
& \Delta t_{b}=\frac{231 \mathrm{~kW} \times 3413(\mathrm{Btu} / \mathrm{hr})(\mathrm{gal} / \mathrm{min})\left(\mathrm{ft}^{3}\right)}{(82)(\mathrm{gal} / \mathrm{min})(8.02)(\mathrm{ft} / \mathrm{hr})(\mathrm{kW})(1.0)\left(\mathrm{Btu} / 1 \mathrm{~b}^{\circ} \mathrm{F}\right)(59)(1 \mathrm{~b})} \\
& \Delta t_{b}=21^{\circ} \mathrm{F}
\end{aligned}
$$

Loop Outlet Water Temperature (Inlet $=200^{\circ} \mathrm{F}$ )

$$
\begin{aligned}
& t_{b}=t_{i n}+\Delta t_{b} \\
& t_{b}=200^{\circ} \mathrm{F}+21=221^{\circ} \mathrm{F}
\end{aligned}
$$

With hot channel factor:

$$
\begin{aligned}
& A_{d j} t_{b}=\left(\operatorname{calc}, \Delta t_{b}\right) F_{B}+\Delta t_{a d d}+t_{i n} \\
& A_{d j} t_{b}=(21)(1.14)+6+200 \\
& A_{d j} t_{b}=230^{\circ} \mathrm{F}
\end{aligned}
$$

\section{Basket Outlet Water Temperature}

Heat transferred to basket coolant $=$ Total $-($ Pressure tube $+1 / 2$ Basket) heat

$$
=231-(23+7)=201 \mathrm{~kW}
$$

Flow rate through basket $=57 \mathrm{gpm}$

$$
\begin{aligned}
& \Delta t_{b}=\frac{(201)(3413)}{(57)(8.02)(1.0)(59)} \\
& \Delta t_{b}=25^{\circ} \mathrm{F} \\
& \text { With hot channei factor: } \\
& A_{d j} t_{b}=(25)(1.14)+6+200 \\
& A_{d j} t_{b}=234^{\circ} \mathrm{F} .
\end{aligned}
$$


Maximum Cladding Surface Temperature

$$
\begin{aligned}
& t_{s}=t_{b}+\Delta t_{f} \\
& \Delta t_{f}=\frac{\left(P_{\text {max }}^{\prime}\right)(3413)(12)}{(\pi D)(h)}=\frac{\text { Surface Heat Flux }}{h} \\
& h=b\left(V \cdot 8 / D_{e} \cdot 2\right) \quad b=475 \quad \text { From Reference } 1, p .52 \\
& t_{s}=\text { Cladding surface temperature, }{ }^{\circ} \mathrm{F} \\
& t_{b}=\text { Bulk water temperature, }{ }^{\circ} \mathrm{F} \\
& \Delta t_{f}=\text { Water film temperature drop, }{ }^{\circ} \mathrm{F} \\
& P^{\prime}{ }_{\text {max }}=\text { Maximum heat rate, kW/ft } . \\
& D=\text { Cladding diameter, in } \\
& h=\text { Water film heat transfer coefficient, Btu/hr-ft }{ }^{2}-{ }_{\circ}^{\circ} \mathrm{F} \\
& V=\text { Coolant velocity, ft/sec } \\
& D_{e}=\text { Flow passage equivalent diameter, in } \\
& b=\text { Factor from Reference } 1
\end{aligned}
$$

Coolant Velocity (57 gpm)

$$
\begin{aligned}
& V=\frac{(57)(.002228) \quad(144)\left(\mathrm{ft}^{3}\right)}{(2.376)^{2}-\left[\frac{\pi}{4}(9)(.75)^{2}\right]\left(\mathrm{ft}^{2}\right)(\mathrm{sec})}=\frac{(57)(.002228)(144)}{1.669} \\
& V=11.0 \mathrm{ft} / \mathrm{sec} \quad V^{\cdot 8}=6.8
\end{aligned}
$$

Basket Bore Equivalent Diameter

$$
\begin{aligned}
& D_{e}=\frac{(4)(1.669)}{[(4)(2.376)+\pi(9)(.75)]} \\
& D_{e}=0.217 \text { in } D_{e}^{\cdot 2}=0.737
\end{aligned}
$$


Heat Transfer Coefficient

$$
\begin{aligned}
& h=b\left(V^{\cdot 2} / D_{e} \cdot 2\right) \\
& h=(475)(6.8) /(.737) \\
& h=4400 \text { Btu/hr-ft }{ }^{\circ}{ }^{\circ} F
\end{aligned}
$$

Water Film $\Delta t$ and Surface Heat Flux

$$
\begin{aligned}
& \Delta t_{f}=\frac{(14.5)(3413)(12)}{(\pi)(.75)(4400)}=\frac{251,000}{4400} \\
& \Delta t_{f}=57^{\circ} \mathrm{F}
\end{aligned}
$$

Surface heat flux $=251,000 \mathrm{Btu} / \mathrm{hr}-\mathrm{ft}{ }^{2}$

\section{Maximum Cladding Surface Temperature}

With hot spot factor:

$$
\begin{aligned}
& t_{s}=t_{\text {in }}+\Delta t_{b} \text { (at hot spot) }+\Delta t_{f} F_{h}+\Delta t_{a d d} \\
& t_{s}=200+15+(57)(1.39)+6 \\
& t_{s}=300^{\circ} \mathrm{F}
\end{aligned}
$$

The saturation temperature at $600 \mathrm{psi}$ is $488^{\circ} \mathrm{F}$.

\section{HOT SPOT AND HOT CHANNEL FACTORS}

A. Mechanical Tolerances

(Hydraulic Effects)
1. Effect on Mass Flow External Effects
1
1
2. Effect on Mass Flow - Entrance and Exit Effects
3. Effect Mass Flow Channel Effects


Hot Channel Hot Spot Additive Factors

Factor, $F_{b-}$ Factor, Fh $\Delta \mathrm{T}$ Add

4. Effect D Variation

$1 \quad 1.01$

B. Mechanical Distortion,

1. Effect on Mass Flow External 1
Effects

2. Effect on Mass Flow Entrance l 1 Effects

3. Effect Mass Flow Channel
Effects

4. Effect D Variation $1.01 \quad 1.01$

C. Correlation Equation on $\mathrm{H} \quad 1$

D. Determination of Critical

Parameters

1. Flow Measurement

2. Temperature Measurements (metal)

1.03

1.03

1.4

3. Pressure Measurements

4. Temperature Measurements (coolant)

1

4.3

E. Flow Distribution Effects

1. Plenum Effects 11

2. Edge Effects 1

F. Neutron and Gamma Flux Distribution

1. Vertical Distribution

1

2. Horizontal Distribution

1

3. Internal Distribution 1

G. Neutron and Gamma Flux Uncertainty

1. Unperturbed Flux Source 


\section{Hot Channel Hot Spot Additive Factors \\ Factor, $F_{b-}$ Factor, Fh $\triangle T$ Add}

2. Average Distribution

3. Experimental Power Generation Variation Timewise

H. Heat Flux Over Element Surface

1. Fuel Homogeneity

2. Mechanical Effects (Mechanical and Clad Thickness)
1

1.1 1

1.1
$1 \quad 1.01$

1

$\overline{1.14} \quad \overline{1.39}$




\section{REFERENCES}

1. R. J. Nertney, Editor, Calculated Surface Temperatures for Nuclear Systems and Analys is of Their Uncertainties, ID0 16343. June 1, 1957. Phillips Petroleum Company, Idaho Fal1s, Idaho. 
OFFICIAL USE ONLY

DISTRIBUTION

No. of

Copies

ONSITE - HANFORD

2

AEC Richland Operations Office

W. E. Fry

H. A. House

$7 \quad$ Battelle-Northwest

J. W. Finnigan

S. Goldsmith

J. W. Kutcher

R. K. Marshall (2)

Technical Files (2)

OFFSITE

4

Battelle-Northwest (NRTS, Idaho Falls)

J. D. Berger (4)

6

Idaho Nuclear Corporation (NRTS, Idaho Falls)

J. T. Cole (3)

B. R. Dabe11 (3) 